\title{
Media Online E-Mail Newsletter Catch Me Up! Konsep dan Inovasi dalam Perkembangan Media Baru
}

\author{
Yuli Indrianti ${ }^{1}$, Dian Wardiana Sjuhro ${ }^{2}$, Nuryah Asri Sjafirah ${ }^{3}$ \\ Fakultas Ilmu Komunikasi, Universitas Padjajaran, Jatinangor, Indonesia \\ e-mail: yuli20002@mail.unpad.ac.id ${ }^{1}$, d.wardiana@unpad.ac.id ${ }^{2}$, nuryah.asri@unpad.ac.id ${ }^{3}$
}

\begin{abstract}
Abstrak
Catch Me Up! merupakan media online pertama di Indonesia yang mempopulerkan e-mail newsletter sebagai model baru sebuah berita media online, konsep dan inovasi yang ditawarkan memberikan kemudahan dan kebaruan dalam memperoleh informasi di tengah maraknya penggunaan smart phone dalam kehidupan sehari-hari. Penelitian ini bertujuan untuk mengetahui bagaiamana e-mail newsletter Catch Me Up! membuat konsep dan inovasi baru dalam perkembangan media baru guna menciptakan media online yang lebih menarik minat baca anak muda, yang memiliki keunikan, dan memiliki sumber data yang valid sehingga dapat memerangi berita hoax dan disinformasi. Penelitian ini menggunakan metode studi kepustakaan dengan mengumpulkan beberapa artikel terkait e-mail newsletter, perkembangan teknologi dan media baru, inovasi media online serta mengumpulkan beberapa sumber penelitian dari website, video wawancara dan gambar mengenai e-mail newsletter Catch Me Up! Kata Kunci: E-mail Newsletter; Inovasi Media Online; Perkembangan Media Baru; Catch Me Up!
\end{abstract}

\begin{abstract}
Catch Me Up! It is the first online media in Indonesia to popularize e-mail newsletter as a new model of online media news, the concepts and innovations offered provide convenience and novelty in obtaining information amid the rampant use of smart phones in everyday life. This research aims to find out how e-mail newsletter Catch Me Up! Create new concepts and innovations in the development of new media to create online media that is more attractive to young people, who have uniqueness, and have valid data sources so as to combat hoax news and disinformation. This research uses the method of literature study by collecting several articles related to e-mail newsletters, new technological and media developments, online media innovations and collecting several research sources from websites, interview videos and images about e-mail newsletters.
\end{abstract}

Keywords: E-mail Newsletter; Online Media Innovation; New Media Developments; Catch Me Up!

\section{Pendahuluan}

Catch Me Up! merupakan media online pertama di Indonesia yang mempopulerkan $e$ mail newsletter sebagai model baru sebuah rangkuman berita dari berbagai isu mulai dari ekonomi, politik, sosial, budaya, hiburan baik berita nasional maupun internasional. Media ini dikemas dalam bentuk online, dapat diakses kapan pun dan di mana pun melalui gadget atau smartphone, media ini menawarkan cara anti ribet dalam memperoleh informasi, selain itu para subscriber akan mendapatkan pengalaman yang berbeda ketika mengkonsumsi berita. Konsep dan inovasi baru yang diusung ini sangat dibutuhkan oleh masyarakat khususnya anak muda agar bisa mendapatkan informasi baru dengan cara yang lebih unik dan menarik, terlebih dapat 
memerangi berita hoax, disinformasi serta meningkatkan literasi (minat baca) sekaligus mengedukasi tentang literasi media agar masyarakat dapat memilih informasi yang lebih bermanfaat.

Newsletter biasanya digunakan untuk marketing dan promosi sebuah perusahaan, kali ini ia hadir dalam bentuk berita yang memberikan informasi umum seputar isu yang sedang berkembang. Untuk memperoleh informasinya, para pembaca harus menjadi subscriber terlebih dahuu dengan cara log-in di website www.catchmeup.id dan klik subscribe dengan memasukkan akun e-mail tanpa dipungut biaya, nantinya setiap hari kerja dari Senin-Jumat pukul 6 pagi Catch Me Up! akan mengirimkan berita pilihan yang sudah dirangkum kepada email masing-masing subscriber, Haifah Inayah selaku CEO Catch Me Up, menjelaskan open rate yang diperoleh, serta jumlah subscriber yang terus meningkat tiap bulannya:

"Saat ini Catch Me Up! sudah memasuki tahun ke-dua dan telah memiliki 50.000 pelanggan yang setiap bulannya naik sekitar 300-400 orang, open rate yang didapatkan cukup tinggi sekitar 40\%, biasanya e-mail newsletter hanya berkisar di angka 8-10\% namun mereka mampu konsisten menjadi berita media online yang menarik para pelanggan untuk terus membuka dan membaca berita yang diberikan "1

Format berita e-mail newsletter Catch Me Up! merupakan sebuah kolaborasi dari perkembangan teknologi, industri media dan industri kreatif, ketiganya menghasilkan sebuah media baru yang memiliki keunikan, perkembangan teknologi mempengaruhi bentuk media yang setiap harinya akan berubah mengikuti arus perubahan dan kebutuhan zaman, penggunaan e-mail sebagai medium penyampai pesan belum pernah digunakan oleh media online di Indonesia, Catch Me Up! menjadi pelopor pertama yang menggunakan e-mail newsletter sebagai medium penyampaian berita umum di media sosial, e-mail merupakan akun utama yang dimiliki setiap orang ketika menggunakan gadget atau smartphone sehingga penggunanya di Indonesia cukup tinggi dan riset menyatakan bahwa anak muda sering membuka e-mail pada pagi hari, hal inilah yang melatarbelakangi Catch Me Up! memilih email sebagai medium pesannya dan target pasarnya adalah kalangan anak muda baik mahasiswa, para pekerja hingga anak sekolahan mereka semua pengguna aktif email. Media sosial seperti Twitter, Facebook, Instagram paling banyak digunakan oleh kalangan remaja dan mahasiswa, mereka cukup adaptif terhadap perkembangan teknologi, para pengguna internet mengaksesnya di atas 7 jam dalam sepekan.

Kemudahan yang ditawarkan menjadi faktor pendorong banyaknya mahasiswa menggunakan media sosial dalam menjalankan aktivitasnya, segala kebutuhan pendidikan, hiburan, informasi ada di dalamya. Riset Yahoo dan Taylor Nelson Sofres (TNS) Indonesia

\footnotetext{
${ }^{1}$ Wawancara Penelitian pada tanggal 14 Juni 2021
} 
pada tahun 2009 dan riset Kemenkominfo bersama APJII pada tahun 2010 memaparkan bahwa remaja adalah pengguna Inetrnet terbanyak di Indonesia dengan jumlah 64\%. Adaptasi yang dilakukan sejalan dengan temuan-temuan sebelumnya yang merujuk bahwa remaja suka mencoba dan memodifikasi hal baru dengan menggunakan teknologi (Badri dan Antin: 2015)

Konsep dan inovasi yang disuguhkan oleh Catch Me Up! sejalan dengan pola konsumsi remaja yang merubah perilakunya dalam mencari kebutuhan informasi serta tingginya jumlah penggunaan email oleh anak muda di Indonesia. Tahun 2018, Google mencatat sebanyak 1,5 miliar pengguna Gmail adalah remaja (Kompas, Oktober 2018). Produk jurnalisme online dengan bentuk seperti ini baru pertama kali digunakan oleh Catch Me Up!, penggunaan judul yang unik dan menarik, bahasa yang kasual dan conversational layaknya percakapan antara teman, bahkan isu yang berat sekalipun dapat dipahami dengan mudah, karena gaya bahasa dan penulisannya ringan, serta konsep yang dijalankan berbentuk rangkuman informasi yang dipilih sehingga memudahkan para pembaca untuk fokus terhadap isu tanpa adanya gangguan dari iklan atau pindah halaman. Catch Me Up! memposisikan diri sebagai media informasi anti ribet, bagi para anak muda yang butuh informasi tetapi mereka tidak punya banyak waktu untuk mencari berita yang sedang update, rangkuman berita yang diberikan akan menceritakan isu yang sedang berlangsung secara jelas, dan detail dengan karakteristik dua bahasa slang.

Berangkat dari keresahan CEO-nya yaitu Haifah Inayah yang sering terganggu dengan iklan dan рор up ketika membaca berita di media online, ia ingin memudahkan para pembaca mendapatkan informasi, dengan cara yang lebih mudah dan murah. Rangkuman berita yang diciptakan ini, diharapkan dapat memenuhi kebutuhan informasi anak muda. Tentunya berita yang dimuat sudah terverifikasi dan tidak mengandung unsur hoax, Catch Me Up! Berupaya meningkatkan literasi (minat baca), masyarakat Indonesia khususnya anak muda, serta mengedukasi tentang literasi media (https://fisipol.ugm.ac.id/digitalk-46-cfds-catch-me-up-memudahkan-konsumsi-berita-sekaligusmeningkatkan-literasi/).

Media baru yang disampaikan oleh McQuail, merupakan media baru yang melahirkan dua arah sehingga, bersifat interaktif kemudian pengolahan dan pendistribusian kontennya beragam, perkembangan media baru yang begitu pesat didukung oleh teknologi komunikasi yang semakin canggih (Kurnia: 2005). Media baru tidak mudah dikontrol dan tidak memiliki hubungan kepemiliklan, media baru lebih individual serta lebih memiliki kekuatan dibandingkan media tradisional sebagai agen perubahan sosial (Kurnia: 2005). Industri media secara perlahan berubah, format dan bentuk komunikasi yang dihasilkan sudah berbeda, media lama masih akan bertahan, tapi perannya akan berubah atau sedikit hilang. Pola produksi, distribusi, bentuk isi/konten dan cara khalayak membaca akan berubah, internet dan teknologi membentuk media online dan surat kabar digital (e-paper). 
OhmyNews adalah situs pertama di dunia yang mengedit, menerima dan mempublikasikan artikel berita yang ditulis oleh pembacanya. Konsep ini berkembang pesat di Korea Selatan sebagai media alternatif atas kontrol pemerintah. OhmyNews dapat dikatakan berhasil sebagai media kritik, mereka bisa berpendapat lewat media online, melibatkan diri pada kepentingan publik (Widodo: 2010). E-Newsletter dapat digunakan untuk menyelenggarakan kegiatan internal suatu perusahaan, salah satunya program diseminasi informasi yang dilakukan oleh lembaga Visual Art Archive Yogyakarta melalui media online yang bersifat internal. Hal ini merupakan strategi baru untuk menyebarkan informasi suatu organisasi kepada khalayak (Setioko: 2019). Era industrialisasi telah berubah ke era informasi yang melahirkan information society (masyarakat informasi). Webster (1995: 6-21) mengungkapkan era masyarakat informasi ini menghasilkan masyarakat yang bergantung pada teknologi yang berkembang dan berinovasi guna mengetahui perubahan dan perkembangan terhadap suatu isu yang ramai diperbincangkan (Kurnia: 2005).

Dalam teori determinisme teknologi: budaya dibentuk dengan bagaimana cara kita berkomunikasi, kehadiran teknologi mempengaruhi manusia dalam berfikir, berpendapat dan berperilaku yang mengarahkan manusia untuk terbawa arus oleh perubahan teknologi, yang kemudian membentuk budaya baru dalam kehidupan manusia sehari-hari (Meisyaroh: 2013), masyarakat harus cerdas menggunakannya jangan sampai teknologi menguasai manusia maka dari itu manusialah yang harus menguasai teknologi agar menghasilkan perilaku yang sesuai norma dan etika yang berlaku namun tetap modern dengan mengaplikasikan teknologi dalam kesehariannya. Namun, media online tetap menjadi wadah dengan banyaknya jumlah informasi yang tidak bisa diverifikasi. Perkembangan teknologi tak lepas dari revolusi ilmu komunikasi, keduanya tidak bisa dipisahkan yang menjadikan fenomena komunikasi mau tidak mau mengalami perkembangan, tanpa adanya komunikasi manusia tidak dapat berinteraksi dan bersosialisasi dengan masyarakat (Zamroni: 2009).

Para jurnalis mengunakan teknologi yang canggih guna mendapatkan sumber yang lebih beragam sehingga dapat menunjang kebutuhan berita, berbagai perangkat aplikasi seperti aviwest on the go dapat diakses di smartphone demi memudahkan liputan (Sucahya:2013). Denis Mc Quail mengungkapkan kemunculan media baru dapat merubah bentuk komunikasi; terciptanya konvergensi dan digitalisasi di seluruh aspek media, meningkatknya konektivitas dan interaktivitas di berbagai jaringan, sehingga masyarakat mudah mengirim dan menerima pesan di berbagai situasi dan kondisi, memahami peran khalayak dan publikasi, munculnya beragam gateway media, lembaga media sudah mulai kabur (Sucahya: 2013). 
Media baru juga berperan dalam memunculkan fenomena berita bohong (hoax), disinformasi dan polarisasi, berita hoax tersebar karena minimnya pengetahuan masyarakat dalam mengidentifikasi berita yang bersumber pada fakta atau rekayasa belaka, sifat mudah percaya dan kecenderungan politik menjadi alasan kuat terhadap isu yang belum jelas kebenarannya, untuk meminimalisir jumlah masyarakat yang mudah percaya berita hoax, perlu adanya literasi media untuk membangun kompetensi publik dalam menerima informasi (Adiprasetio, Gumgum dan Maharani : 2017). Produksi dan penyebaran berita buruk tersebut sulit dibendung dan media sosial menjadi sarana distribusi konten yang paling banyak digunakan. Kecepatan dan kemudahan menjadi alasan utama penyebar konten untuk mendapatkan keuntungan yang dapat memecah belah bangsa dengan berita yang tidak benar dan saling adu domba (Febriansyah dan Muksin: 2020).

Media baru hadir untuk mengubah platform dan cara mengemas informasi, isi berita adalah hasil konvergensi dari kecanggihan teknologi. Kemajuan teknologi membentuk karakteristik pesan yang dibuat oleh media online dan internet yang dapat dengan mudah menciptakan media sendiri, bagaimana fungsi jurnalistik mulai dari merencanakan liputan, menuliskan hasil liputan, mengedit tulisan, memuat dan menyebarkannya di berbagai situs Internet. Saat ini semua orang yang memiliki internet bisa menjadi "jurnalis dadakan," meski tentu saja kualitas jurnalistik mereka masih bisa kita perdebatkan (Muslimin: 2011). Jurnalisme adalah aktivitas yang dilakukan oleh jurnalis mulai dari mencari, memproduksi, menyebarkan informasi kepada publik, sementara digital merupakan konsep yang dimiliki oleh teknologi komputer dengan istilah kode biner (Ashari:2019). Latar belakang keduanya apabila dipadukan akan melahirkan istilah jurnalisme digital yaitu proses pencarian, pengolahan dan pendistribusian informasi yang akan disampaikan kepada khalayak di mana data yang dihasilkan berbentuk teks yang ditampilkan melalui teknologi melalui perangkat komputer dan koneksi internet.

Media online dan jurnalistik online pertama berkembang pada 1995 - 1997 dengan hadirnya internet di Indonesia, media baru (new media) adalah hasil dari perkembangan teknologi komputer, sementara media digital merupakan teknologi berupa medium yang memiliki karakteristik teknologi digital (Dewdney and Ride dalam Hadi: 2009). Internet juga mengubah konsep jurnalisme, secara cepat informasi dapat disebarkan saat itu juga "real time”, dan ini merupakan perkembangan yang mutakhir pada dunia jurnalistik di Indonesia. Industri media saat ini harus mengikuti perkembangan teknologi dan zaman, salah satunya tren jurnalisme data yang disuguhkan oleh Tirto.id., jurnalisme data yang dimaksud adalah dengan mengumpulkan berbagai data yang dimuat secara menarik dan menyeluruh dengan 
sentuhan ide kreatif seperti visualisasi, infografik serta interaktif. Manajemen redaksional media online ini memiliki beberapa tahapan mulai dari perencanaan, pelaksanaan, pengawasan hingga evaluasi, setiap orang ikut andil alam proses perencanaan yang dibagi secara merata sehingga setiap anggota ikut serta dalam proses pembuatan berita baik hard news, current issue, mild news dan indepth reporting (Prasetyanti :2018).

\section{Literatur Riview}

Inovasi dan konsep yang diadaptasi oleh CatchMeUp ini bentuk dari pemanfaatan dan perkembangan teknologi guna menciptakan media baru yang belum pernah ada sebelumnya di Indonesia. Peneliti terdahulu memaparkan bahwa Bengkulu news.co.id melakukan inovasi dengan membuat ciri khas pada tampilan pemberitaan dan halamannya yang memuat berita secara lengkap sehingga masyarakt tidak kesulitan mengakses portalnya (Adek, Yanto dan Lorita: 2017).

CatchMeUp! tidak menggunakan konsep dan karakteristik media online kebanyakan di Indonesia, ia hadir untuk memberikan informasi, edukasi dan hiburan dari rangkuman informasi yang bersumber pada data yang jelas, bahasa layaknya percakapan digunakan agar pesan mudah dipahami dan pastinya informasi yang diberikan selalu up to date. Penelitian sejenis terdahulu membahas tentang bagaimana peran media komunikasi dan informasi berupa media sosial yang efektif untuk dijadikan media komunikasi dan informasi dalam menyampaikan aspirasi dan masalah yang dialami oleh masyarakat khususnya di daerah yang belum terkoneksi internet dengan dan tidak diketahui oleh pejabat daerahnya. Hasil penelitiannya menjelaskan bahwa apabila suatu media komunikasi dapat berperan dalam membentuk jaringan sosial masyarakat yang dilakukan dengan cara yang benar, beretika, dan dapat dipertanggungjawabkan kebenarannya maka pembangunan nasional akan terwujud. Hal ini tentunya membutuhkan kerjasama antara pemerintah dan masyarakat untuk mengadakan kegiatan penyuluhan dalam menghadapi era digital, dibutuhkannya edukasi dan literasi agar masyarakat dapat melakukan aktivitas digitalnya dengan cara yang baik dan benar (Suri :2019).

Namun media dan jurnalis perlahan kabur, orang yang dapat menyebarkan informasi lewat media online disebut publisher, mereka yang menulis berita disebut jurnalis, hal ini tentu harus diperhatikan karena mereka bukanlah orang yang berpengalaman untuk disebut sebagai publisher dan jurnalis. Media tradisional dinilai lebih memiliki kredibilitas dibandingkan dengan media online, hal ini terjadi karena obyektivitas media tradisional dijamin dan didukung oleh gate keeper. Berita yang dihasilkan diolah, disaring, editor mengontrol isi dan fakta yang ditulis pada sebuah berita. Sementara media online dengan 
mengunggulkan kecepatan sering memasukkan berita yang sumbernya tidak jelas, informasinya kurang akurat dan cenderung tidak cover both sides (Widodo:2010).

Profesionalitas media online dicap tidak memiliki kredibilitas yang memumpuni, karena proses yang ditempuh dinilai tidak berpedoman pada etika profesionalitas jurnalistk (Muliawati: 2018). Permasalahan yang muncul biasanya plagiasi, kurangnya verifikasi terhadap sumber berita dan hasil berita yang dimuat melahirkan fenomena jurnalisme judul. Berita yang dimuat dapat menimbulkan chungking journalism berupa penyampaian infomasi yang dipenggal kemudian disambungkan pada halaman lain yang ditujukan agar para pembaca meng-klik tautannya guna meningkatkan jumlah klik pada halaman iklan (Muliawati: 2018). Konten media sangat dipengaruhi isu dan interkasi yang terjadi di media sosial. Media menghadirkan segmentasi khusus untuk pembaca, positioning dan monetisasi mengubah cara bisnis media di era digital saat ini. Keuntungan yang didapatkan mengandalkan iklan dan jumlah klik, konten media harus menarik dengan menyajikan data infografis, sketsa dll (Indainanto:2021). Media online seharusnya tidak boleh mengabaikan kepentingan publik, verifikasi dan akurasi harus dijaga walaupun tuntutan penyajian secara cepat menjadi pedomannya. Media online tidak boleh mengabaikan etika jurnalistik agar informasinya tetap bermanfaat dan dapat dipercaya (Adzkia dalam Puspita dan Suciati: 2020).

\section{Methods}

Peneliti ini menggunakan jenis penelitian studi kepustakaan (library research), dengan cara megumpulkan data dan informasi dengan dukungan, bahan lainnya yang diperoleh melalui dokumen, artikel, berita, website, buku, visual dsb (Mardalis dalam Mirzaqon:2018). Studi kepustakaan juga menyertakan buku dan penelitian yang sejenis sebelumnya, menjadi referensi data guna mencari permasalahan yang akan diteliti (Sarwono:2006). Jenis pendekatan penelitian ini adalah kajian teoritis yang menggunakan literatur ilmiah sebagai referensi, yang berkaitan dengan budaya, norma, nilai, yang berkembang saat penelitian ini dilakukan (Sugiyono:2012). Metode penelitian ini digunakan, untuk mengetahui bagaimana proses awal mula email newsletter Catch Me Up, menciptakan inovasi dan membantuk konsep rangkuman berita yang unik, sehingga memiliki karakter dan ciri khas tersendiri. Data yang dijadikan sumber oleh peneliti terdiri dari 1 buku, 23 jurnal, 1 artikel, 1 naskah Publikasi, 1 video youtube wawancara dan wawancara langsung dengan Haifah Inayah selaku CEO Catch Me Up. Teknik Analisis Data Teknik analisis data yang 
digunakan dalam penelitian ini adalah metode analisis isi (Content Analysis). Analisis ini digunakan untuk mendapatkan inferensi yang valid dan dapat diteliti ulang berdasarkan konteksnya (Kripendoff dalam Mirzaqon: 2018).

\section{Result}

Berdasarkan temuan yang dilakukan peneliti, maka ditemukan beberapa inovasi yang dibuat oleh Catch Me Up! sebagai bentuk media baru, pertama dengan menggunakan e-mail sebagai medium penyampaian pesan, kedua dengan mengusung konsep gaya bahasa kasual, slang bahasa inggris dan bahasa indonesia yang ditampilkan dengan gaya percakapan. Ketiga menggunakan, sumber media yang sudah terverifikasi. Inovasi yang diciptakan ini, sejalan dengan upaya dari pemanfaatan teknologi yang banyak digunakan oleh remaja di Indonesia, sehingga langkah ini dianggap tepat karena sesuai dengan target pasar yang dituju yaitu para remaja dan mahasiswa yang sering membuka e-mail. Gaya bahasa yang kasual dan conversational layaknya percakapan memudahkan para pembaca untuk memahami informasi yang diberikan, termasuk pemberian judul yang menarik, interaktifitas dan hypertext. Pengolahan pesan secara digital, dan pendistribusian pesan melalui e-mail para subscriber merupakan keunikan yang ditawarkan, oleh Catch Me Up! sebagai berita media online yang mempopulerkan istilah e-mail newsletter atau platform news curator berita pertama di Indonesia.

Pada artikel yang menjadi sumber studi pustaka di atas, sudah dijelaskan bahwa konsep media baru yang dikemukakan Mc Quail terdapat di dalam berita Catch Me Up!, dampak negatif dari media online memang lebih banyak karena kecepatan dan kemudahan yang ditawarkan tidak dapat dihindari sehingga masih banyak berita dari media online yang diragukan akan nilai dan kredibilitasnya, media online dinilai tidak kredibel karena proses pengolahan dan pendistribusiannya tidak terverifikasi dengan baik (Muliawati: 2018).

Media online berperan dalam memunculkan fenomena berita bohong (hoax), disinformasi, polarisasi dan propaganda. Kemenkominfo menyebutkan terdapat 800.000 situs penyebar hoax di Indonesia dan media online menjadi sumber utama penyebarannya, sistem produksi dan distribusinya pun sulit dibendung sehingga mengakibatkan bangsa terpecahbelah dengan berita yang tidak benar dan saling adu domba (Febriansyah dan Muksin: 2020). Media online dianggap kurang memiliki kredibilitas karena nilai beritanya tidak akurat, marak plagiasi, saling adu cepat sehingga mengakibatkan minimnya verifikasi terhadap sumber berita (Muliawati:2018). Berita hoax mudah tersebar dan diterima karena minimnya 
pengetahuan masyarakat dalam mengidentifikasi berita yang bersumber pada fakta atau hanya rekayasa belaka (Adiprasetio, Gumgum dan Maharani: 2017).

\section{Discussion}

Untuk mendukung tujuan Catch Me Up!, yang ingin membuat masyarakat peduli terhadap isu sekitar dan kondisi saat ini, mereka juga ingin meningkatkan literasi atau minat baca anak muda di Indonesia serta mengedukasi tentang pentingnya literasi media. Kepedulian yang dimaksud adalah tentang kondisi yang terjadi di Indonesia baik kondisi ekonomi, politik, lingkungan, dan pemerintahan agar anak muda bisa ikut berperan dalam mewujudkan serta menggagas ide baru atas permasalahan yang sedang dihadapi. Literasi atau minat baca anak muda di Indonesia juga masih sangat kurang maka dari itu CatchMeUp!, hadir sebagai sarana guna meningkatkan minat baca mereka dengan cara yang unik, sehingga membaca berita pun terasa menyenangkan dan tidak bosan.

Literasi media bagi masyarakat dalam mengakses informasi dan tontonan harus ditekankan agar terhindar dari berita bohong, disinformasi, polarisasi, propaganda serta tontonan yang tidak bermanfaat. Edukasi ini ditujukan untuk semua kalangan baik anak-anak, remaja, dewasa bahkan orang tua harus diberikan pemahaman untuk bisa memilih dan menyaring hiburan dan informasi yang ditayangkan melalui media massa maupun media online, apa yang ditayangkan oleh media adalah hasil konstruksi yang dibentuk oleh media. Peran keluarga, lingkungan, orang tua dalam membentuk budaya membaca dan menonton televisi memiliki dampak yang besar bagi anak sehingga pendidikan ini harus diberikan secara menyeluruh agar menghasilkan masyarakat yang bijak dan cerdas dalam memilih informasi dan tontonan (Darwadi:2017).

Kehadiran internet mempermudah manusia untuk saling berkomunikasi dari jarak jauh. Salah satu bentuk perkembangan teknologi adalah hadirnya media baru atau lebih dikenal dengan media sosial, yang memunculkan budaya, tren, gaya hidup baru dari budaya luar (global village) yang saling dipertukarkan lewat media sosial. Perubahan yang terjadi adalah budaya, jenis komunikasi dan penggunaan alat-alat komunikasi yang canggih salah satunya adalah temuan baru media online e-mail newsletter Catch Me Up! yang memiliki konsep dan inovasi dalam perkembangan media baru di Indonesia.

Media baru (new media) adalah hasil dari perkembangan teknologi komputer, sementara media digital merupakan teknologi berupa medium yang memiliki karakteristik teknologi digital, terciptanya konvergensi dan digitalisasi di seluruh aspek media, meningkatknya konektivitas dan interaktivitas di berbagai jaringan sehingga masyarakat 
mudah mengirim dan menerima pesan di berbagai situasi dan kondisi, memahami peran khalayak dan publikasi, munculnya beragam gateway media, lembaga media sudah mulai kabur (Sucahya:2013). Produk media yang dihasilkan anak bangsa masih belum banyak menjadi konsumsi utama di Indonesia, keunikan dan variasi menjadi daya tarik Catch Me Up! untuk mendapatkan pelanggan sebanyak-banyaknya sehingga mereka tidak bosan membaca berita .

Pengguna internet saat ini 202,6 juta jiwa atau 73,7 \% dan 170 juta jiwa atau $61,8 \%$ aktif dalam bermedia sosial. Sementara itu berdasarkan faktor usia, dari seluruh populasi penduduk di Indonesia, data pengguna internet paling banyak adalah mereka yang berumur 13 tahun ke atas sebanyak 231,2 juta orang atau 77,5\%, sementara itu 69,1\% adalah mereka yang berumur 18 tahu ke atas dengan jumlah 190,1 juta orang https://datareportal.com/reports/digital-2021-indonesia.

Media baru tentunya membawa dampak yang positif dan negatif, dampak yang positif berupa peluang membuka lapangan kerja dan kemudahan mendapatkan pekerjaan di bidang teknologi, media dan digital yang membutuhkan banyak pekerja di dalamnya, selain itu relasi dan hubungan dengan orang yang sulit dijangkau dapat dengan mudah terhubung, terciptanya komunitas, organisasi, budaya yang dipertukarkan (global village), berbagai bentuk pesan dapat tercipta dari berbagai saluran (Kurniawan:2005), kemudahan, kecepatan dalam membuat dan membagikan pesan kepada siapa saja dan di mana saja dapat dengan mudah dilakukan.

Namun dampak negatif juga bermunculan, seperti kriminalitas dan tindak kejahatan lainnya, minimnya sikap sopan santun terhadap sesama pengguna juga sering terjadi karena kurangnya pengetahuan masyarakat, dalam bermedia sosial, bahkan masyarakat Indonesia dinobatkan menjadi warga net yang paling tidak sopan di Asia Tenggara, riset yang dilakukan oleh Micosoft ini dilaporkan oleh Digital Civility Index (DCI), mereka mengukur tingkat kesopanan pengguna internet di Indonesia memiliki poin 76, semakin tinggi angkanya maka semakin buruk hasilnya, https://www.cnnindonesia.com/teknologi/20210225115954-185610735/riset-netizen-di-indonesia-paling-tak-sopan-se-asia-tenggara.

Maka dari itu, Indonesia membutuhkan edukasi penggunaan media sosial dan platform media baru, guna memenuhi kebutuhan informasi, agar masyarakat mudah memahami isi beritanya, sehingga para pembaca mendapatkan ilmu dan perspektif baru. Semakin banyak bentuk media online yang beredar, maka semakin beragam pula pesan yang dihasilkan, namun yang paling sering membuat propaganda sebuah informasi adalah pesan visual digital diantaranya foto, gambar, animasi, video dan tipografi (Khairil:2018). 
Proses distribusi konten yang mudah dilakukan oleh siapa pun ini membawa dampak buruk karena semua orang dapat mengolah dan mendistribusikan pesan tanpa sumber yang jelas, fenomena yang terjadi seperti cyber-bullying, hacking, cracking, dan pemalsuan identitas akan merugikan masyarakat yang menggunakan media sosial, selain itu marak juga plagiasi, data bocor, pembajakan dan pencurian informasi (Khairil:2018). Untuk menghindari besarnya pengaruh buruk teknologi dan media sosial maka dibutuhkan peran keluarga, masyarakat dan negara (Ngafifi:2014) sehingga pengawasan dapat berjalan, tata krama dan sopan santun juga ditanamkan agar menghasilkan para netizen yang sopan dan cerdas dalam memberikan komentar, membagikan pesan serta membuat konten yang bermanfaat.

Berikut adalah gambar dari laman website CatchMeUp! ketika kita mengaksesnya, terdapat informasi untuk bisa menjadi pelanggan (subscriber), mengapa pembaca harus memilih CatchMeUp sebagai media informasi, ulasan para pembaca yang merekomendasikan CatchMeUp! sebagai media online baru dalam memenuhi kebutuhan informasi anak muda dan informasi lainnya

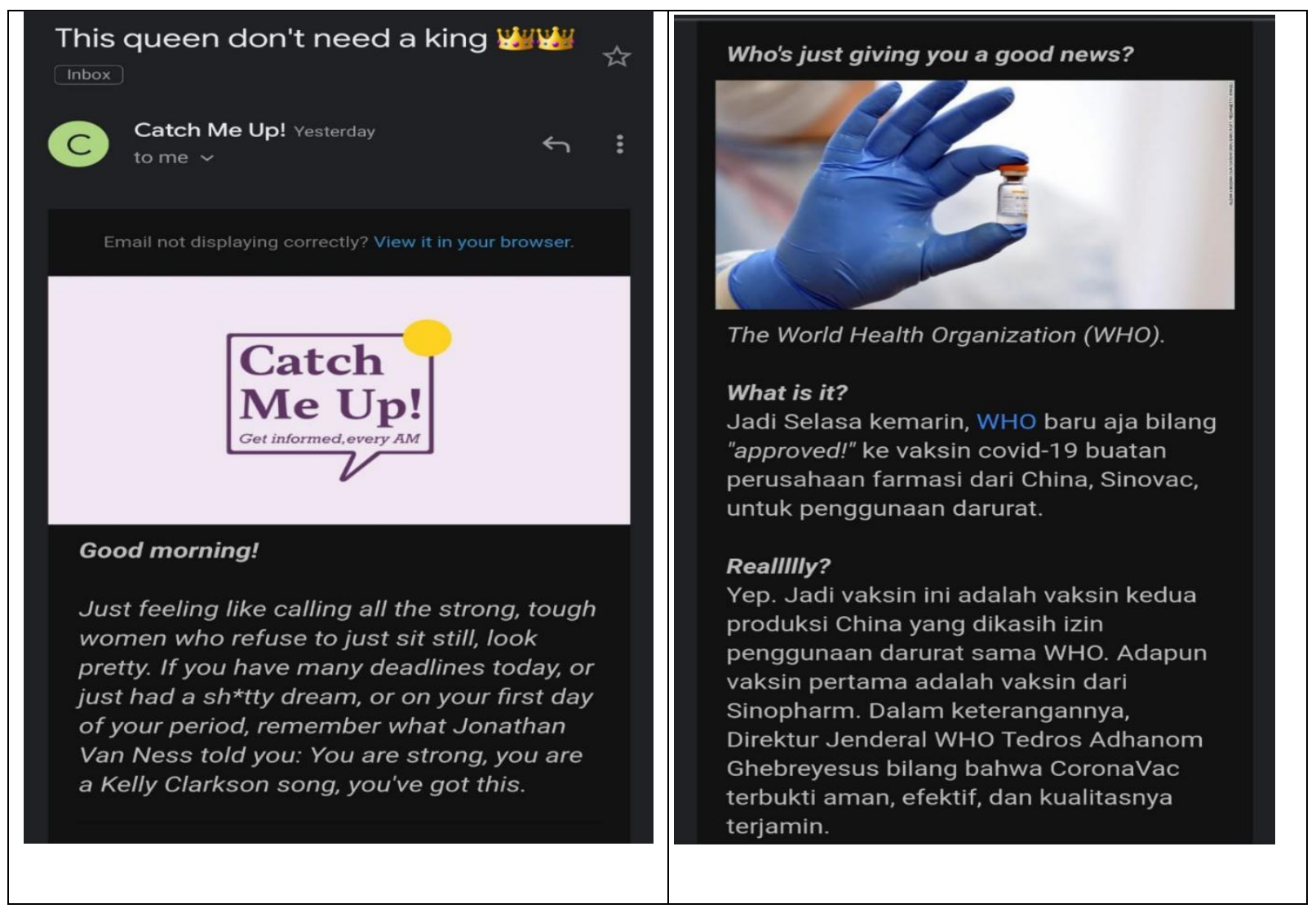




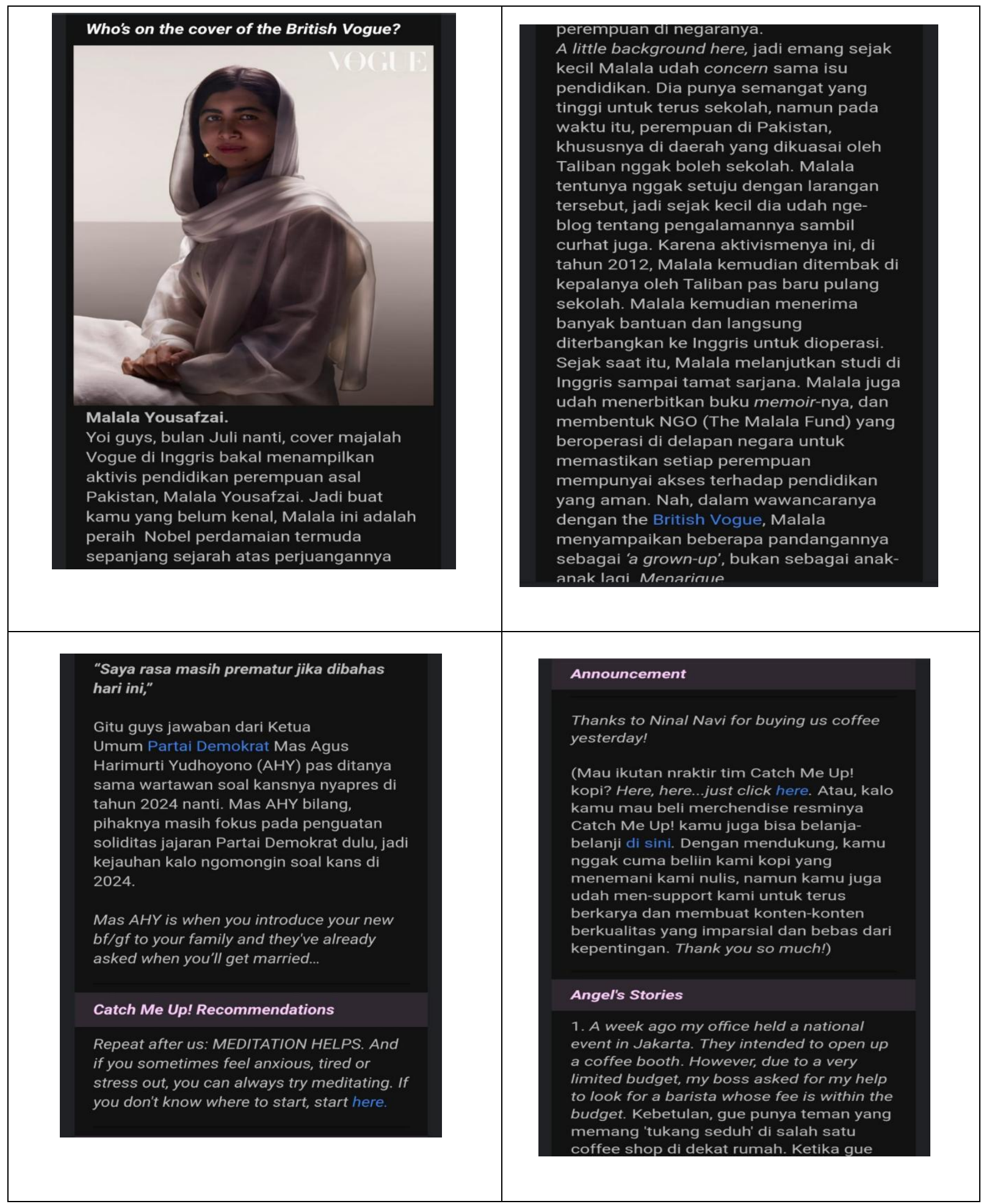

Sumber: E-Mail Newsletter CatchMeUp!, 2021

Lister menggambarkan konsep perkembangan media baru, ada 5; digitality, interactivity, hypertextuality, dispersal dan virtuality. Proses media digital dibentuk, diubah dan disimpan ke dalam bilangan dan akan ditampilkan dalam bentuk 'hard copy'. Interactivity menggambarkan konsep sebuah teks yang dapat dikomentari dan saling berkomunikasi antara penulis dan pembaca, Lister menyebut kata 'hype' dalam hypertext 
sebagai kata kunci merujuk pada karakteristik media baru yang hadir sebagai teks di luar dari teks itu sendiri, hypertext / hypermedia teks dari konten lain masih pada satu isu namun berbeda sumber, dispersal adalah bentuk distribusi dan produksi yang mengunggulkan keaktifan seorang, virtuality (Hadi:2009).

Konsep yaang dipaparkan Lister di atas, telah diterapkan dan diaplikasikan oleh Catch Me Up!, media ini diakses dengan menggunakan teknologi berbasis digital dan virtual yang dapat diakses melalui gadget, smartphone, laptop dll. Di dalamnya para pelanggan dapat berinteraksi dengan menceritakan pengalamannya di kolom Angel's Story dan tentu interaktifitas terjadi di dalamnya, konten ini dibuat oleh mereka yang memahami dengan seksama isu yang akan diangkat, dengan mencantumkan sumber berita pada hypertext, sehingga apabila para pelanggan masih belum merasa puas oleh berita yang ditulis Catch Me Up!, mereka dapat mengakses melaluilink sumber berita, yang disediakan untuk mencari tahu berita yang sama namun dari sumber yang berbeda.

Jenis media baru ini adalah media online yang terkoneksi dengan internet, seperti media dotcom, cyber media dan jurnalisme online, produksi media online relatif lebih murah karena tidak memerlukan kertas sebagai bahan baku percetakan, karakteristik media baru menurut Feldman (1997) dalam Hastjarjo (2012: 144): adalah mudah dimanipulasi, karena semua orang dapat melakukannya dengan bebas dan mudah, tanpa adanya pengawasan dan aturan, bersifat networkable karena konten yang dihasilkan dapat dibagikan dan dipertukaran dengan mudah, compressible karena ukuran konten dapat diperkecil dan dikurangi agar mudah disimpan dan dibagikan, tanpa khawatir ukuran kontennya terlalu besar, dinilai padat karena dapat menyimpan konten di dalam space yang kecil, imparsial karena konten yang disajikan tidak memiliki keberpihakan pada kelompok penguasa, oleh karenanya media sosial disebut mdeia yang demokratis.

Adapaun kelemahan media online dalam praktik jurnalisme online, kecepatan menjadi keunggulanya namun beritanya belum tentu akurat, banyaknya copy paste dan plagiarisme. Manusia di era saat ini sangat bergantung dengan teknologi dan media sosial, untuk itu diperlukan media sosial yang mampu meningkatkan kualitas informasi dan manusianya itu sendiri, filterisasi harus dilakukan agar masyarakat tidak mudah percaya dengan berita hoax yang tersebar di media sosial (Rosana: 2010).

Media online memiliki keistimewaan diantaranya: khalayak bebas memilih berita yang diinginkan (audience control), berita yang muncul berdiri sendiri (nonlienarity), berita dengan mudah dapat disimpan dan diakses kembali di waktu yang berbeda (storage and retrieval), pilihan dan sumber berita lebih lengkap (unlimited space), berita tersebar dengan 
sangat cepat (immediacy), pekerja media dapat memasukkan fitur baru untuk melengkapi berita baik gambar animasi, suara,foto, video, teks dll (multimedia capability), terjadinya interaksi dua arah (interactivity) (Widodo: 2010). Media tradisional dinilai lebih memiliki kredibilitas dibandingkan dengan media online, hal ini terjadi karena obyektivitas media tradisional dijamin dan didukung oleh gate keeper. Berita yang dihasilkan diolah, disaring, editor mengontrol isi dan fakta yang ditulis pada sebuah berita. Sementara media online mengunggulkan kecepatan sering memasukkan berita yang sumbernya tidak jelas, informasinya kurang akurat dan cenderung tidak cover both sides (Widodo: 2010).

Manajemen redaksional Catch Me Up!, tidak menerapkan kecepatan dalam menyebarkan informasi, apa-apa saja yang dilakukan oleh media online mainstream tidak diterapkan di dalamnya, mereka hanya ingin menjadi media online yang beda dalam penyajian berita, cara mudah mengakses berita tanpa ribet danmemberikan pengalaman baru dalam membaca, serta mengkonsumsi berita agar tidak mudah bosan. Proses pengolahan dan distribusi, dilakukan oleh tim penulis yang mengambil berita dengan sumber yang jelas, dengan menyertakan hypertext di dalam bahan beritanya. Berita yang dimuat adalah berita yang sudah berlangsung kurang lebih, satu hari sebelum e-mail newsletter dipublikasikan kepada para pelanggan, jadi rangkuman beritanya tidak sepenggal, karena Catch Me Up! berupaya untuk bisa menjelaskan secara detail atas isu yang terjadi.

\section{Conclusion}

Catch Me Up! menjadi media online yang mengedepankan kepentingan publik, meningkatkan literasi atau minat baca anak muda, sekaligus mengedukasi literasi media kepada masyarakat, untuk bisa memilih media yang lebih sehat dan bermanfaat. Catch Me Up! Menciptakan berbagai inovasi, agar mampu bersaing dengan media online lainnya, penggunaan e-mail sebagai medium penyampaian pesan, konsep newsletter yang dirangkum menjadi daya tarik pembaca, gaya bahasa kasual dengan memadukan slang bahasa inggris dan bahasa indonesia, yang konsep percakapan, dan menggunakan sumber media yang sudah terverifikasi. Hadirnya Catch Me Up ini, juga turut meningkatkan kepedulian anak muda, akan isu yang berkembang, sehingga mereka bisa lebih peduli terhadap lingkungan sekitar. Apabila anak muda, peduli maka hal itu akan meningkatkan integritas masyarakatnya khusunya anak muda, media menjadi salah satu cara membentuk karakter bangsa yang bermoral dan berpendidikan, melalui media yang sehat maka masyarakat akan lebih cerdas. 


\section{Refrences}

Adek, Ferizal. Yanto. Lorita, Evi. (2017) Inovasi Media Online Dalam Menghadapi Persaingan Media Massa di Kota Bengkulu. Jurnal Professional FIS UNIVED Vol. 4 No. 2 Desember 2017

Adiprasetio,Justito. Gumilar, Gumgum, Hartoyo dan Nunik Maharani. (2017). Hoax, Reprodduksi dan Persebaran:Suatu Penelusuran Literatur. Jurnal Pengabdian Kepada Masyarakat Vol. 1, No. 4

Andrew, Richard. (2018). Inovasi Untuk Media Sosial Ciptaan Indonesia. Jurnal Muara Ilmu Ekonomi dan Bisnis. Vol. 2 No. 1 April 2018: 29-34

Ashari, Muhammad. (2019). Inter Komunika: Jurnal Komunikasi Vol 4, No 1, Th 2019, 1-16 P-ISSN: 25483749 E-ISSN: 26154420

Badri, Muhammad. Antin, Titin. (2015). Adopsi Inovasi Media Sosial Mahasiswa Jurusan Ilmu Komunikasi FDK UIN SUSKA RIAU. Jurnal RISALAH, Vol. 24. No.6 Desember 2015: 183-196

Darwadi. (2017). Media Baru Sebagai Informasi Budaya Global. Jurnal Komunikator. Vol. 9, No.1 Mei 2017

Digitalk \#46 CfDS: Catch Me Up! Memudahkan Konsumsi Berita sekaligus Meningkatkan Literasi (2021, Maret 5). Diakses dari https://fisipol.ugm.ac.id/digitalk-46-cfds-catchme-up-memudahkan-konsumsi-berita-sekaligus-meningkatkan-literasi/

Febriansyah. Muksin, Nani Nurani. (2020). Fenomena Media Sosial: Antara Hoax, Destruksi Demokrasi, dan Ancaman Disintegrasi Bangsa. SEBATIK Vol. 24, No. 2

Hadi, Ido Prijana. (2009). Perkembangan Teknologi Komunikasi Dalam Era Jurnalistik Modern. Jurnal Ilmiah SCRIPTURA, Vol.3, No.1, Januari 2009:69-84

Ikhsan, M. (2021). Riset: Netizen di Indonesia Paling Tak Sopan se-Asia Tenggara https://www.cnnindonesia.com/teknologi/20210225115954-185-610735/risetnetizen-di-indonesia-paling-tak-sopan-se-asia-tenggara. (diakses pada tanggal 24 Desember 2021, pukul 11.50 WIB).

Indainanto, Yofiendi Indah. (2021). Masa Depan Media Massa di Era Digital. Jurna Ilmiah Muqoddimah: Jurnal Ilmu Sosial, Politik dan Humaniora E-ISSN : 2598-6236

Khairil, Muhammad. (2018). Analisis Pemanfaatan New Media Melalui Jaringan Media Sosial. National Conference of Creative Industry: Sustainable Tourism Industry for Economic Development. Universitas BundaMulia, Jakarta, 5-6 September 2018 ISSN No: 2622-7436

Kurnia. Novi. (2005). Perkembangan Teknologi Komunikasi dan Media Baru : Implikasi Terhadap Teori Komunikasi. MEDIATOR Vol. 6 No.2 Desember 2005

Meisyaroh, Siti. (2013). Determinisme Teknologi Masyarakat Dalam Media Sosial. Jurnal Komunikasi dan Bisnis Vol. 1, No. 1

Mirzaqon, Abdi. (2018). Studi Kepustakaan Mengenai Landasan Teori dan Praktik Konseling Expressive Writing. Jurnal BK Unesa. Vol. 8 No.1 
Muliawati, Lintang. (2018). Jurnalisme Digital: Dari Pengumpulan Inormasi Sampai Penyebaran Pesan Jurnalisme Era Digital: Digitalisasi Jurnalisme dan Profesionalitas Jurnalisme Online. Jurnal Lentera, Vol. II, No.1, Juni 2018

Muslimin, M. (2011). Perkembangan Teknologi dalam Industri Media. Jurnal Teknik Industri, Vol. 12, No.1, Februari 2011:57-64

Ngafifi, Muhammad. (2014). Kemajuan Teknologi dan Pola Hidup Manusia dalam Perspektif Sosial Budaya. Jurnal Pembangunan Pendidikan Fondasi dan Aplikasi Vol. 2 No.1

Puspita, Ratna. Suciati, Titis Nurulan. (2020). Mobile Phone dan Media Sosial: Penggunaan dan Tantangannya pada Jurnalisme Online Indonesia. Ekspresi dan Persepsi: Jurnal Ilmu Komunikasi, Vol.3 No. 2 Januari 2020 e-ISSN:2656-050Xn

Rosana, Anita Septiani. (2010). Kemajuan Teknologi Informasi dan Komunikasi dalam Industri Media di Indonesia. Jurnal GEMA EKSOS Vol. 5, No.2

Setioko, Muhammad Amir. Krismayani Ika. (2019). Diseminasi Informasi E-Newsletter melalui Komunikasi oleh Indonesian Visual Art Archive Yogyakarta. Jurnal Ilmu Perpustakaan Vol. 6 No. 4

Sugiono. (2008). Metode Penelitian Bisnis: Pendekatan Kualitatif, Kualitatif dan R\&D. Bandung: ALFABETA

We Are Social. "Digital 2020: Indonesia.” Global Digital Insights, 2020, p. 17, https://datareportal.com/reports/digital-2021-indonesia. (diakses pada tanggal 24 Desember 2021, pukul 11.50 WIB). 